\title{
The Effect of Entrepreneurship Learning and Emotional Intelligence on Entrepreneurial Intention
}

\author{
Kurjono $^{1, *}$, Leni Yuliyanti ${ }^{1}$, Saripudin ${ }^{1}$ \\ ${ }^{1}$ Universitas Pendidikan Indonesia \\ *Corresponding Author.Email: kurjono@upi.edu
}

\begin{abstract}
The study aims at identifying the effects of entrepreneurial learning and emotional intelligence on entrepreneurial intentions and the differences of entrepreneurial intentions based on the gender aspect. This study employed an explanatory survey method involving 560 accounting education students from all over Indonesia as the research population. Then, 233 respondents were acquired as the sample size. The data collection was carried out using the questionnaires that firstly have been tested for their validity and reliability. In addition, this study also employed descriptive and regression analysis as a means of processing the data. The research findings show that entrepreneurship learning and emotional intelligence have a positive and significant effect on entrepreneurial intentions. Learning entrepreneurship has the greatest influence on entrepreneurial intentions. There is no difference in entrepreneurial intentions from the gender aspect, it is suggested that the two independent and dependent variables increase the facilities and infrastructure indicators, indicators of social skills, and indicators of enthusiasm for trying a business.
\end{abstract}

Keywords: Entrepreneurial Intentions, Learning, Entrepreneurship, Intelligence, Emotions

\section{INTRODUCTION}

Entrepreneurship is considered as a potential resource in economic growth [1]. The academic and learning systems implemented in tertiary institutions are supposed to prepare graduates who are ready to create jobs. Among the determinants of entrepreneurial intention, entrepreneurship education is an important factor, because previous research evidence shows that there is a clear relationship between entrepreneurship education and entrepreneurial activities [2].

Additionally, it is due to the fact that entrepreneurship can be taught to students [3]. However, experts also agree that guiding students to become entrepreneurs cannot be done through classical entrepreneurship education in the classroom. In addition, it must also provide opportunities to learn to gain experience through conducting direct observation of entrepreneurial activities. According to [3] entrepreneurship education should provide more opportunities to engage in work-learning activities and learn the experience of running a business. In other words, entrepreneurship can be studied in informal and formal education.

\section{ENTREPRENEURSHIP LEARNING AND EMOTIONAL INTELLIGENCE AS IMPORTANT FACTORS OF ENTREPRENEURIAL INTENTIONS}

Entrepreneurship learning is the cultivation of values, abilities, and behaviors in creation and innovation in establishing one's entrepreneurial spirit [4]. Therefore, entrepreneurship learning aims to teach students to start running a successful and profitable new business and it can also contribute to the economic growth [5]. Thus, entrepreneurship learning has a positive effect on entrepreneurial intentions [6]. however, this contradicts the results of Oosterbeek's research [7]. Emotional intelligence according to plays an important role in predicting the entrepreneurial process [8]. Emotional intelligence is regarded as the ability to recognize, evaluate, and express emotions, and generate feelings that affect the way a person thinks [9]. Therefore, individuals are competent to become entrepreneurs if they are confident in their 
ability to regulate their emotions and recognize the emotions of others. The results of studies showed that emotional intelligence has a positive effect on entrepreneurial intentions, [10] as found by [11] and [12].

Emotional intelligence is related to entrepreneurial behavior and success, personality trait control, demographic variable, and individual differences in entrepreneurial personality [13]. Learning entrepreneurship and emotional intelligence in influencing entrepreneurial intentions is still inconsistent, so the author will re-examine the topic, if applied to accounting education students in Indonesia.

\section{RESEARCH METHOD}

The research population involved in this present study are 560 Accounting Education students from all over Indonesia. They are taking Accounting Education Study Program, the bath 2018, from Universitas Negeri Medan, Universitas Pendidikan Indonesia, Universitas Negeri Makasar, Universitas Negeri Yogyakarta, Univeristas Negeri Malang and Universitas Negeri Surabaya. In addition, they also have attended entrepreneurship courses. This study employed the sample size formula by Isaac Michael [14] and 233 respondents were obtained as the research samples.

The exogenous variable, referring to Suherman [15], is the entrepreneurial learning $\left(X_{I}\right)$ which consists of the indicators of learning objectives, learning materials, learning methods, infrastructure, evaluation, and teachers. The emotional intelligence variables $\left(X_{2}\right)$, referring to Goleman [16], consist of the indicators of self-awareness, self-control, motivation, empathy, and social skills. Meanwhile, the endogenous variable, referring to Krueger [17], is Entrepreneurial Intentions (Y) which consist of the indicators of the spirit of doing and planning a business. In particular, the operationalization of variables is explained in Table 2. This study employed a closed questionnaire as the data collection technique distributed by google form on a numerical scale. In addition, the instruments also have been tested in terms of their validity and reliability test.

The data analysis was carried out using variable description analysis and regression analysis. The variable description analysis is presented using calculating percentages, such as tables and graphs. After passing the classical assumption test, namely data normality test, heteroscedasticity test and autocorrelation test, hypothesis testing then used regression analysis. The proposed model is shown in the following figure.

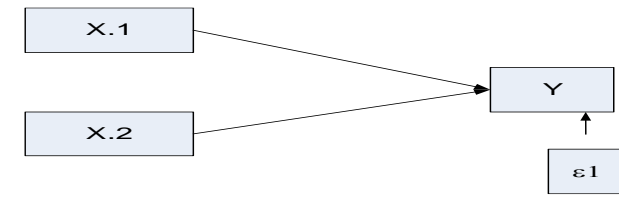

Figure 1. Research Model

Information:

$X_{1}=$ Entrepreneurship Learning

$X_{2}=$ Emotional Intelligence

$Y=$ Entrepreneurial Intentions

$e_{1}=$ Other factors besides Entrepreneurial Intentions

\section{FINDING AND DISCUSSION}

Based on Table 1 on the Gender Aspect, it is found that the profiles of students who became respondents were mostly female $(82 \%)$ and the rest were male $(18 \%)$.

Table 1. Respondents by Gender

\begin{tabular}{lll}
\multicolumn{1}{c}{ Gender } & \multicolumn{1}{c}{ F } & \multicolumn{1}{c}{ Percentage } \\
\hline Male & 43 & $18.00 \%$ \\
Female & 190 & $82.00 \%$ \\
\hline Total & 233 & $100.00 \%$
\end{tabular}

Source: processed data, 2020

Entrepreneurial learning $\left(X_{-}\right.$1) in high condition. Emotional intelligence (X_2) is in moderate condition, while entrepreneurial intention is high. The effect of the two variables obtained $\mathrm{R} 2=0.190, \mathrm{~F}=27.027(\mathrm{P}$ $=0.000)$ significant testing. This means that the more positive learning entrepreneurship and emotional intelligence, the higher the entrepreneurial intention, the amount of influence is $19 \%$, while the remaining $81 \%$ is influenced by other variables. The results of hypothesis testing are shown in Table 2 as follows.

Table 2. Hypotheses Testing

\begin{tabular}{|c|l|c|l|l|}
\hline Variables & $\mathrm{B}$ & $t_{\text {hit }}$ & $\mathrm{Sig}$ & Criteria \\
\hline & 10,520 & 4,69 &, 000 & \\
\hline$X_{1}$ &, 196 & 5,92 &, 000 & $H 0$ rejected \\
\hline$X_{2}$ &, 165 & 3,16 &, 002 & $H 0$ rejected \\
\hline
\end{tabular}

Source: processed data, 2020

Based on the table above the structural equation is $Y=10,520+0,196 X_{1}+0,165 X_{2}$

Partial testing shows that entrepreneurial learning towards entrepreneurial intentions is supported by 
data, which means that for each increase of 1 unit of entrepreneurial learning, entrepreneurial intentions increase by 10.716 . Because entrepreneurship can be learned, it means that early entrepreneurship learning activities determine career choices for entrepreneurship [19]. The results of hypothesis testing support the results of research [19] although it is different from the study, [20]. Emotional intelligence (X2) on entrepreneurial intention (Y) is supported by data, the more positive emotional intelligence, the higher the entrepreneurial intention. equal to 10.685 , the higher the emotional intelligence, the higher the entrepreneurial intention. The testing is in line with the research results of [21] and [22]. Emotional intelligence can increase entrepreneurial intentions. Individuals who have emotional intelligence tend to show a high tolerance for pressure and the environment [23]. They have the potential to develop a more positive attitude to starting their business, and prefer a higher risk. Students with knowledge of their emotions can channel negative or positive affections on the identification and resolution of problems relevant to the creation of the right business. The importance of emotional intelligence, because it has a relationship with creative and innovative attitudes among students [24]. Individuals with high emotional intelligence can generate creative ideas, which form entrepreneurial characteristics [25]. The following is an empirical research model.

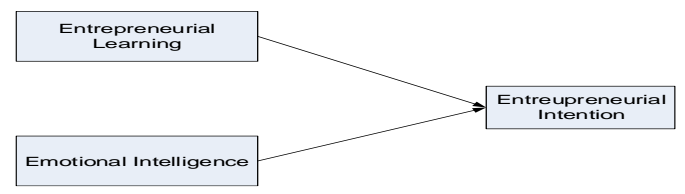

Figure 2. Empirical Model

Test the difference in entrepreneurial intentions seen from the gender aspect. presented in table 3 .

Table 3. Gender comparative test

\begin{tabular}{|c|c|c|c|}
\hline \multirow{2}{*}{$\begin{array}{l}\text { Levene's Test for Equality of } \\
\text { Variances }\end{array}$} & \multicolumn{3}{|c|}{ Gender } \\
\hline & $\mathbf{F}$ & Sig. & $\mathbf{t}$ \\
\hline Intenti & 0,174 & 0,677 & 0,0 \\
\hline
\end{tabular}

Source: processed data, 2020

Based on table 4, comparative testing is supported by data. This is in line with the study [27]

\section{CONCLUSIONS AND SUGGESTIONS}

Learning entrepreneurship and emotional intelligence can increase entrepreneurial intentions, therefore it needs to be maintained. The findings show that entrepreneurial learning has a greater influence on entrepreneurial intentions. Because there is no difference in entrepreneurial intentions in terms of gender, men and women must be facilitated to participate in entrepreneurial competition activities.

Entrepreneurship learning needs to be improved, especially the indicator of university entrepreneurship incubators. Through the media, the intensity will increase. Emotional intelligence needs to be improved, especially indicators of social skills, because successful business activities are based on social interactions. Entrepreneurial intention needs to be improved, especially in the indicator of the spirit of trying a business. This can be done through entrepreneurial motivation by lecturers both in interncurricular and extracurricular activities.

\section{ACKNOWLEDGMENTS}

To all Accounting Education lecturers, entrepreneurship lecturers throughout Indonesia and all Accounting Education students throughout Indonesia

\section{REFERENCES}

[1] Liñán, F., Rodríguez-Cohard, J. C.,\& RuedaCantuche, J. M. Factors affecting entrepreneurial intention levels: A role for education. International Entrepreneurship and Management Journal, 7(2), $2011 . \quad 195-218$. https://doi.org/10.1007/s11365-010-0154-Z

[2] Galloway, L. and Brown, W., "Entrepreneurship education at university: a driver in the creation of high growth firms?", Education Training, Vol. 44 No. 8/9, 2002, pp. 398-405.

[3] Lackeus, M. Developing Entrepreneurial Competencies: An action approach and classification in entrepreneurial education. Thesis for the degree of licentiate of engineering. Gothenburg, Sweden: Division of Management of Organization Renewal and Entrepreneurship, Department of Technology Management and Economics, Chalmers University of Technology. 2013.

[4] Danuhadimedjo., R. Djatmiko. Kewiraswastaan dan Pembangunan. Bandung: Alfabeta. 2010.

[5] Tung, L. C. The Impact of Entrepreneurship Education on Entrepreneurial Intention of Engineering Students. 11(1), 2011. 67-86.

.[6] Puspitaningsih, Flora Pengaruh Pendidikan Kewirausahaan dan Lingkungan Keluarga terhadap Minat Wirausaha dengan Self Efficacy sebagai Variabel Intervening pada Mahasiswa 
STKIP PGRI Trenggalek, Jurnal Dewantara Volume 2. Nomor 1. Maret. 2016

[7] Oosterbeek, H., Van Praag, M. and Ijsselstein, A. "The impact of entrepreneurship education on entrepreneurship skills and motivation", European Economic Review, Vol.54 No. 3, 2011. pp. $442-454$

[8] Mortan, R.A., Ripoll, P., Carvalho, C. and Bernal, M.C. "Effects of emotional intelligence on entrepreneurial intention and self-efficacy", Journal of Work and Organizational Psychology. 30 No. 3, 2014, pp. 97-104.

[9] Salovey, P., \& Mayer, J. Emotional intelligence. Imagination, Cognition and Personality, 9(3), 1990, 185-211. https://doi.org/10.2190/DUGGP24E-52WK-6CDG

[10] Kanonuhwa, M., Rungani, E.C. and Chimucheka, T. "The association between emotional intelligence and entrepreneurship as a career choice: a study on university students in South Africa", SA Journal of Human Resource Management, Vol. 16, 2018. pp. 1-9

[11] Davis, P.E. and Peake, W.O., "The influence of political skill and emotional intelligence on student entrepreneurial intentions: an empirical analysis", Small Business Institute Journal. 10 No. 2, 2014, pp. 19-34

[12] Archana, R.V. and Kumari, K.V.," Study on the influence of emotional intelligence on entrepreneurship intention", International Journal of Pure and Applied Mathematics, Vol. 119 No. 12 , 2018, pp. 14839-14851

[13] Ahmetoglu, G., Leutner, F., \& ChamorroPremuzic, T., EQ-nomics: Understanding the relationship between individual differences in Trait Emotional Intelligence and entrepreneurship. Personality and Individual Differences, 51, 2011, 1028-1033. doi: http://dx.doi.org/10.1016/j.paid.2011.08.016

[14] Sugiyono. Metodologi Penelitian Administrasi, edisi kelima. Bandung: Alfabeta. 2004.

[15] Suherman, Eman Desain Pembelajaran Kewirausahaan. Bandung: Alfabeta. 2010.

[16] Goleman, D. Kecerdasan Emosi untuk Mencapai Puncak Prestasi, Teorj. dari Working with Emotional Intelligence oleh Alex Tri Kantjono Widodo, Jakarta: PT Gramedia Pustaka Utama, 2005.
[17] Krueger, M.D.Reilly, and Carsrud, "Competing models of entrepreneurial intention,"Journal of Business Venturing, Vol. 15, 2000, pp. 411-32

[18] Drucker, P.F. Innovation and Entrepreneurship, Harper \& Row Publisher, New York (Alih bahasa oleh Naib,R.(1991) Inovasi dan Kewiraswastaan, Penerbit Erlangga, Jakarta). 1991.

[19] Anggraeni, B. Pengaruh Pengetahuan dan Lingkungan Keluarga terhadap Minat Berwirausaha Siswa Kelas XI SMK Islam Nusantara Comal Kabupaten Pemalang. Jurnal Pendidikan Ekonomi Dinamika Pendidikan. Vol. X. No. 1 Juni 2015. https://journal.unnes.ac.id/nju/index.php/DP/arti cle/view/5093

[20] Mentoor, E.R. and Friedrich, C., "Is entrepreneurial education at South African universities successful? An empirical example", Industry and Higher Education, Vol. 21 No. 3, 2007, pp. 221-232.

[21] Archana, R.V. and Kumari, K.V., "Study on the influence of emotional intelligence on entrepreneurship intention", International Journal of Pure and Applied Mathematics, Vol. 119No. 12, 2018, pp. 14839-14851

[22] Mortan, R.A., Ripoll, P., Carvalho, C. and Bernal, M.C., "Effects of emotional intelligence on entrepreneurial intention and self-efficacy", Journal of Work and Organizational Psychology. 30 No. 3, 2014, pp. 97-104

[23] Mikolajczak, M., Luminet, O., \& Menil, C., Predicting resistance to stress: Incremental validity of Trait Emotional Intelligence over Alexithymia and Optimism. Psicothema,18, 2006, 79-88

[24] Othman, N. and Muda, T., "Emotional intelligence towards entrepreneurial career choice behaviours", Education+Training, Vol. 60 No. 9, 2018, pp. 953-970

[25] Ngah, R. and Salleh, Z, "Emotional intelligence and entrepreneurs' innovativeness towards entrepreneurial success: a preliminary study", American Journal of Economics, Vol. 5 No. 2, 2015, pp. 285-290

[26] Also, G., \& Isaksen, E. Closing the gender gap? Entrepreneurial training and entrepreneurial intentions among male and female youth. Paper presented at the 17th Nordic Conference on Small Business Research, Helsinki. 2012. 